Птахіна Ольга Миколаївна

(C) Птахіна O. М., 2017

Луганський національний університет імені Тараса Шевченка,

м. Старобільськ

\title{
ФОРУВАННЯ ПРОФЕСІЙНОЇ МОБІЛЬНОСТІ МАЙБУТНІХ ФАХІВЦІВ В ПРОЦЕСІ НАВЧАННЯ У ВНЗ
}

Вимогою сучасного суспільства до системи вищої освіти є ефективна професійна підготовка майбутнього фахівия, який зможе легко пристосуватися до мінливих умов сьогодення та бути конкурентоспроможним на ринку праці. Обтрунтовано важливість формування професійної мобільності в прочесі навчання у ВНЗ. Визначено сутність поняття професійної мобільності та складові професійної мобільності майбутнього фахівия. Професійна мобільність передбачає володіння фахівцем компетенціями, що уможливлюють гнучкість, швидку орієнтацію у професії, готовність до підвищення кваліфікації, перекваліфікащії та самоосвіти.

Ключові слова: професійна мобільність, компетенції, компетентність, компетентнісний підхід.

Проблема, ïï зв'язок із важливими науковими чи практичними завданнями. Державний напрямок на євроінтеграцію вимагає якісно нової та досконалої підготовки конкурентоспроможних фахівців, які мають бути готовим до систематичного оновлення свого багажу знань, освоєння нових технологій та інформаційних джерел. На передній план виходить така якість фахівця, як професійна мобільність, що $є$ запорукою успішності молодої людини у сучасному суспільстві. Нові реалії сьогодення ставлять перед вищою освітою абсолютно нові вимоги щодо підготовки фахівців, тому ми вважаємо, що підготовка професійно мобільних кваліфікованих фахівців $\epsilon$ головним завданням вищих навчальних закладів.

Аналіз публікацій (виділення невирішених проблем). Питанню формування професійної мобільності приділяють увагу все більше коло вчених таких, як О. І. Архангельський, Н. В. Василенко, Л. В. Горюнова, М. Джеджула, Є. А. Іванченко, С. Е. Каплина, С. А. Кугель, Н. В. Коваліско, Л. І. Нічуговська, Н. С. Мерзлякова, Е. В. Сайфутдинова, Л. Л. Сушенцева, І. В. Шпекторенко. На сьогодні актуалізується проблема підготовки професійно мобільного фахівця, який зможе реалізувати себе на ринку праці як кваліфікований професіонал. Однак, незважаючи на дослідження цих та багатьох інших учених, проблема лишається актуальною. 


\section{Збірник наукових статей}

Ціллю статті $\epsilon$ обгрунтування необхідності формування професійної мобільності майбутніх фахівців в процесі навчання у ВНЗ.

Виклад основного матеріалу, обгрунтування результатів дослідження. Фундаментальні реформи у галузі вищої освіти в Україні та перехід на нову педагогічну парадигму, що зорієнтована на особистість, зумовили появу підгрунтя для формування професійної мобільності у сучасних фахівців. У сучасних умовах глобалізації та модернізації вищої професійної освіти актуальним $є$ завдання підготовки фахівців, здатних не тільки легко навчатися, швидко пристосовуватися до мінливих умов і змісту професійної діяльності, але і зацікавлених у своїй безперервній освіті та ії вдосконаленні.

У літературних джерелах зустрічаються такі визначення професійної мобільності, як: якість особистості, що дозволяе ій бути соціально активною, конкурентоспроможною, професійно компетентною, здатною до саморозвитку й модернізації власної діяльності та зміни видів діяльності; здатність і готовність особистості досить швидко і успішно оволодівати новою технікою і технологією, набувати відсутні знання і вміння, що забезпечують ефективність нової профорієнтаційної діяльності; здатність швидко змінювати вид праці, переключатися на іншу діяльність у зв'язку зі змінами техніки й технології виробництва, що виявляється у володінні системою узагальнених прийомів професійної праці та застосуванні їх для успішного виконання будь-якого завдання на суміжних за технологією ділянках виробництва та інші [7].

Отже професійна мобільність це інтегрована якість особистості, яке включає в себе здатність та готовність фахівця до зміни професії, місця i роду діяльності, самоорганізацію та саморегуляцію особистості.

Спираючись на компетентнісний підхід у вивченні професійної мобільності, вчені дійшли висновку, що формування професійної мобільності фахівця можливе через розвиток компетенцій. Загальною ідеєю компетентнісного підходу є компетентнісно орієнтована освіта, яка спрямована на комплексне засвоєння знань та способів практичної діяльності, завдяки яким людина успішно реалізує себе в різних галузях своєї життєдіяльності. Компетентнісний підхід у вищій освіті охоплює поряд із знаннями і навичками такі категорії, як здібності, готовність до пізнання, соціальні навички. Компетентнісний підхід дозволяє розкрити бажаний результат освіти через сукупність різного виду компетенцій. Використання компетентнісного підходу в освіті передбачає використання таких технологій навчання, у котрих всі педагогічні процеси спрямовуються на диференційований розвиток i саморозвиток особистості. 
Головне завдання вищого навчального закладу полягає в тому, щоб за допомогою сучасних форм і методів навчання і навчальнометодичного матеріалу, збезпечити цілеспрямований розвиток у студентів розумових здібностей, інтересу до навчальної роботи, самостійності і творчості. Саме активні форми і методи навчання сприяють формуванню у студентів психологічної готовності до професійної діяльності, а в подальшому і до професійної мобільності. Компетентнісний підхід дозволяє розкрити бажаний результат освіти через сукупність різного виду компетенцій. Спираючись на компетентнісний підхід, науковці стверджують, що на формування професійної мобільності фахівця в процесі навчання у ВНЗ впливає розвиток певних компетенцій та компетентностей:

- соціально-комунікативні компетенції та компетентності, які забезпечують готовність майбутнього фахівця до використання комунікативних технологій і соціалізації в сучасному світі;

- освітні компетенції та компетентності, що характеризують готовність майбутнього фахівця до наукового, системного пізнання світу, до оволодіння навичками самостійного освоєння знань i підвищення своєї кваліфікації або зміну професії, підтримуванню свого професійно-творчого і соціального потенціалу в умовах науковотехнічного прогресу на належному рівні, а також до самовдосконалення і самоосвіти;

- загальнонаукові компетенції та компетентності, які забезпечують високий рівень базових загальних знань і загальних знань за профілем спеціальності, а також здатність адаптуватися до змін змісту соціальної та професійної діяльності;

- ціннісно-смислові та загальнокультурні компетенції та компетентності, що забезпечують успішність ціннісносмислової орієнтації фахівця у світі, готовність i прагнення пізнати i удосконалювати самого себе, навколишню дійсність, готовність до творчої діяльності, оволодіння високим рівнем професійної культури $[3 ; 6]$.

Отже, професійна мобільність передбачає володіння фахівцем компетенціями, що уможливлюють гнучкість, швидку орієнтацію у професії, конкурентоздатність на ринку праці, готовність до підвищення кваліфікації, перекваліфікації та самоосвіти. Чинниками, що зумовлюють необхідність формування професійної мобільності у майбутніх фахівців, є: інноваційні процеси у суспільстві; швидке старіння знань; залежність успішності в житті від рівня освіти і професії; динамічність і швидкозмінність вимог на ринку праці; поява нових професій і зникнення застарілих.

Висновки, перспективи. Компетенції та компетентності $\epsilon$ основною складовою формування професійної мобільності фахівця. 


\section{Збірник наукових статей}

Отже головною метою сучасної вищої освіти є підготовка фахівців, зацікавлених у своїй безперервній освіті та вдосконаленні, а також здатних легко навчатися, швидко пристосовуватися до мінливих умов i змісту професійної діяльності. Процес навчання майбутніх фахівців у ВНЗ повинен проходити за допомогою використання сучасних форм $\mathrm{i}$ методів навчання й навчально-методичного матеріалу, які мають забезпечувати формування в майбутнього фахівця таких особистісних якостей та здібностей, які дозволили б йому самостійно орієнтуватися в професійному світі, планувати кар'єрний ріст, розширювати свої професійні можливості, освоюючи нові сфери професійної діяльності.

Професійна мобільність є важливою якістю фахівця. Забезпечувати іiї формування під час навчання у вищому навчальному закладі необхідно, оскільки це готує майбутніх фахівців до змін, які виникають у нашій державі в зв'язку з політичною та економічною ситуацією.

\section{Література}

1. Александров Д. В. Освітні потреби населення в контексті розширення інформаційного простору / Д. В. Александров // Український соціум. - 2011. - № 1. - С. 7-14.

2. Арефьев О. Н. Самоорганизация образовательной системы, направленной на формирование социально-профессиональной мобильности человека в XXI веке / О.Н.Арефьев // Социальнопрофессиональная мобильность в XXI веке : Сборник материалов и докладов Международной конференции. - Екатеринбург, 2014. - С. 15 20.

3. Зимняя И. А. Ключевые компетентности как результативноцелевая основа компетентностного подхода в образовании / И. А. Зимняя. - М. : Исследовательский центр проблем качества підготовки специалистов, 2004. - 42 с.

4. Іванченко С. А. Формування професійної мобільності майбутніх економістів у процесі навчання у вищих навчальних закладах: дис. ... канд. пед. наук : 13.00.04 «теорія та методика професійної освіти»/ Іванченко Євгенія Анатоліївна; Південноукр. держ. пед. ун-т ім. К. Д. Ушинського. - Одеса, 2005. - 262 с.

5. Кузьміч Т. А. Проектування педагогічного простору для стимулювання внутрішньої i зовнішньої мобільності учасників навчально-виховного процесу: метод. рек. / Т. А. Кузьміч, К. М. Товстуха; Херсонська академія неперервної освіти. - Херсон, 2012. $-18 \mathrm{c}$.

6. Сушенцева Л. Л. Теоретико-методичні засади формування професійної мобільності майбутніх кваліфікованих робітників у професійно-технічних навчальних закладах: дис. ... д-ра. пед. наук: 13.00.04 / Сушенцева Лілія Леонідівна. - Київ, 2012. - 559 с. 
7. Латуша Н. В. Понятя «Професійна мобільність» у педагогічному аспекті / Н. В. Латуша // Наукові записки Вінницького держ. пед. ун-ту ім. М. Коцюбинського. Серія: Педагогіка і психологія [зб. наук. праць]. - Вінниця, 2014. - Вип. 42, Ч. 2. - С.6-9.

\section{Ольга Птахина. Формирование профессиональной} мобильности будующих специалистов в процессе обучения в ВУЗе. Требованием современного общества к системе высмего образования является эффективная профессиональная подготовка будущего специалиста, который сможет легко приспособиться к меняющимся условиям настоящего и быть конкурентоспособным на рынке труда. Обоснована важность формирования профессиональной мобильности в прочессе обучения в вузе. Определена сущность понятия профессиональной мобильности, составляющие профессиональной мобильности будущего специалиста. Профессиональная мобильность предполагает владение специалистом компетенииями, позволяющими быть гибким, быстро ориентироваться в профессии, готовность $\kappa$ повыщению квалификации, переквалификачии и самообразованию.

Ключевье слова: професина мобильность, компетенциии, компетентность, компетентностный подход.

\section{Olga Ptakhina. Formation of professional mobility of future} specialists in the process of training at the university.

The system requirement of modern society higher education effective professional preparation of future specialist that will be able easily to adjust to the changing terms of present and be competitive at the market of labour is. Importance of forming of professional mobility is reasonable in the process of educating in institution of higher learning. The essence of the concept of professional mobility, which is the professional mobility of the future specialist, is determined. Professional mobility supposes possession a specialist competenses allowing to be flexibility, quickly oriented in professions, readiness to in-plant training, retraining and self-education.

Keywords: professional mobility, competence; competency; competencebased approach.

Стаття надійшла до редакційної колегії 30.05.2017 